\title{
Investigation of Mechanical Properties for Titanium Alloy TI-6AL-4V-SS316
}

\author{
P. Arulmurugan ${ }^{1 *}$, J. Venkatraman ${ }^{2}$, P. Saravanan ${ }^{3}$ \\ ${ }^{1}$ Student, Department of Mechanical Engineering, Mahendra Engineering College, Namakkal, India \\ ${ }^{2}$ Assistant Professor, Department of Mechanical Engineering, Mahendra Engineering College, Namakkal, India \\ ${ }^{3}$ Professor \& HoD, Department of Mechanical Engineering, Mahendra Engineering College, Namakkal, India \\ *Corresponding author: arulmurugan4301@gmail.com
}

\begin{abstract}
Titanium and its alloys are being extensively research and are applied relatively in different field of dentistry in since 1970s. Inherent advantage like high strength, ductility, Low modules of plasticity, high corrosion resistance as titanium alloy (Ti 6A 4V ELI -SS316). It is also light weight and highly tolerant to damage by other the alloy content. It is iron are mixing so forming the corrosion resistance and magnetism effect. So to add aluminum, vanadium and carbon content increases and iron content was decrease the various percentage for metal matrix composite(MMC) methods and stainless steel ss316 add by using stir casting method, and to check the hardness test, corrosion test and chemical specification and mechanical properties of the materials. To avoid the bone cells loss and bone desorption. It has superior biocompatibility making it easy to gratin and attach to bone all which being accepted by the human body.
\end{abstract}

Keywords: Stainless steel ss316, Stir casting, Titanium alloy Ti 6A 4V ELI.

\section{Introduction}

This paper is organized as, firstly, a brief overview of titanium and its alloys including alloy classification, micro structural features and phase transformations. Secondly, characteristics of titanium alloys, particularly Ti-6Al-4V (Ti64) and Ti-6Al-2Sn-4Zr-6Mo (Ti6246), And thirdly, micro structural phenomena in titanium alloys such as texture development and variant selection are summarized. The demand for machining of titanium alloy has been increased in recent years. In order to understand and access the current status of research in machining of titanium alloys

Ti 6Al-4V (Grade 5) Ti-6AL-4V is the most commonly used of the currently medical application. It is therefore commonly referred to titanium alloy "workhorse." It is believed to use in of the usage of titanium around the world. These desirable properties make Ti-6AL-4V is several industries including medical, marine, aerospace and chemical. Ti $6 \mathrm{AL}-4 \mathrm{~V}$ is commonly used:

- $\quad$ Aircraft turbines

- Engine components

- Aircraft structural components

- Aerospace fasteners
- High-performance automatic parts

- Marine applications

- $\quad$ Sports equipment

\section{A. Ti 6AL-4V ELI (Grade 23)}

Ti 6 AL-4V ELI is commonly referred to surgical materials. It is a purer version of Grade 5 ( $\mathrm{Ti} 6 \mathrm{AL}-4 \mathrm{~V}$ ) titanium alloy. It can be used easily molded, and cut into small strands, coils, and wires. It has the same strength, and high corrosion resistance as Ti 6AL-4V. It is also light-weight and is highly tolerant to damage compared by other alloys. Its use is highly desirable in the medical and dental fields for uses in complex surgical Procedures not only because of these properties but also because of the unique surgical properties Ti 6AL-4V ELI has. It has superior biocompatibility making it easy to graft in and attach to bone all the while being accepted easily by the human body. Some of the more common surgical procedures Ti 6AL$4 \mathrm{~V}$ ELI is used in include, this type of titanium used application are up to 400 degrees Celsius and density of roughly 4420 $\mathrm{kg} / \mathrm{m}^{\wedge} 3$ then the youngs modulus is $120 \mathrm{gpa}$

Standard specification are:

AMS:4911,4928 6930, 6931, T-9046

ASTM: B265, B348

MIL: T9046

- Orthopedic pins and screws

- Orthopedic cables

- Ligature clips

- Surgical staples

- Springs

- Orthodontic appliances

- In joint replacements

- Cryogenic vessels

- Bone fixation devices

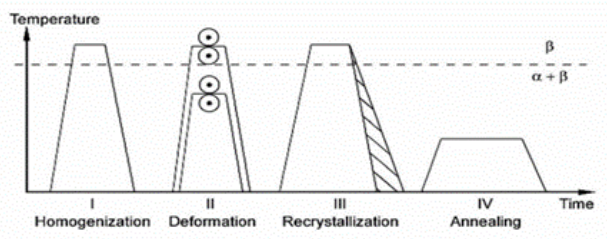

Fig. 1. 
Physical Properties of type 316 and 316L steels:

- Density: $0.799 \mathrm{~g} / \mathrm{cm}^{3}$

- Electrical resistivity: 74 microhm-cm (20 degrees Celsius).

- Specific Heat: $0.50 \mathrm{~kJ} / \mathrm{kg}-\mathrm{K}$ (0-100 degrees Celsius).

- Thermal conductivity: $16.2 \mathrm{~W} / \mathrm{m}-\mathrm{k}$ (100 degrees Celsius)

- Modulus of Elasticity (MPa): 193 x 103 in tension.

- Melting Range: 2,500-2,550 degrees Fahrenheit (1,3711,399 degrees Celsius).

\section{Casting Process}

Metal casting process begins by creating a mold, which is the 'reverse' shape of the part we need. The mold is made from a refractory material, for example, sand. The metal is heated in an oven until it melts, and the molten metal is poured into the mould cavity. The liquid takes the shape of cavity, which is the shape of the part. It is cooled until it solidifies. Finally, the solidified metal part is removed from the mould.

In stir casting process, the mechanical stirrer is coupled with the varying speed motor to control the speed of the stirrer. There are various stages of impeller stirrer i.e. single stage, double stage and multistage impeller. Double stage and multi stage stirrer are mainly used in chemical industries whereas single stage impeller stirrer is commonly used for fabrication of AMCs and HAMCs due flexibility and to avoid excessive vortex flow. Below figure shows various stages of impeller stirrer.

Stirring plays a vital role over the final microstructure and mechanical properties of the casted composites as it controls the distribution of reinforcements within the matrix. Optimum mechanical properties can be attained by the uniform distribution of reinforcement and this problem is a common to most of processing techniques, including stir casting. This problem can be solved by optimal selection of stirring parameters.

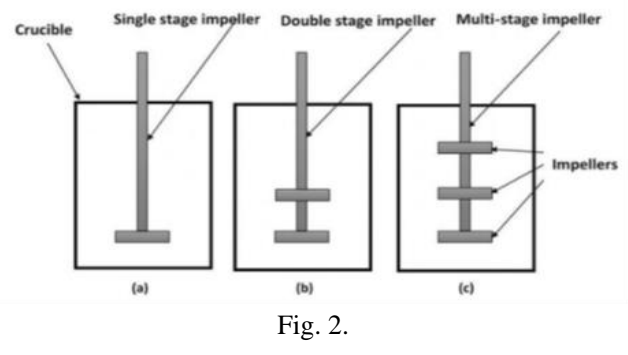

Mechanical properties of AMCs and HAMCs mainly depends on the dispersion of the reinforcements throughout the composite. The dispersion of reinforcements is governed by stirring parameters. Hence, performing experiment with selecting random stirring parameters may not provide homogeneous dispersion of reinforcement particle which leads to lower mechanical properties. Therefore, understanding of effect of stirring parameters and selection of optimal stirring process parameters is crucial. Stirring speed is to be maintained between 500-700rpm for a time period of 10-15 minutes

- Casting can produce very complex geometry parts with cavities and hollow sections.

- It can be used to make small (few hundred grams) to very large size (thousands of kilograms)

- Common examples: door handles, locks, the outer casing or housing for motors, pumps, etc., wheels of many cars. Casting is also heavily used in the toy industry to make parts, e.g. toy cars, planes, and so on.

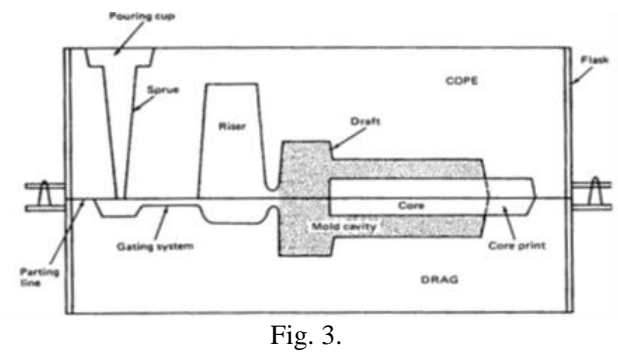

\section{Tensile Testing}

Universal hydraulic servo-controlled machine $40 \mathrm{kN}$ capacity, computer controlled, to perform static tensile tests on metallic materials.

It basically consists of:

- Strong loading frame with a reading strain gage load cell built into the piston.

- Computer Controlled System SCM3000 and software, for the data acquisition, control and processing.

- Hydraulic Power Pack: adapted to the users specific needs: range of force, speed, stroke, type of control, etc. The whole is built in a console.

- The frame is designed to carry out tensile tests using the grips placed in the clamping heads. In the upper part, between the head and traverse,

- It is possible to carry out flexion, compression, bending, hardness, dishing tests, according to the International Standards by using the suitable (see accessories) devices.

- The hydraulic servo-controlled unit regulates the load or the displacement rate by the Computer.

- An emergency device stops the machine in any moment as per the International Safety Standards.

- A control panel situated on the frame governs the movement of the lower tensile head (typical excursion $0 \div 300 \mathrm{~mm}$ with electric end of stroke switches) for an easier positioning of the specimen according to its length.

- The machine is supplied complete with loading frame, control system SCM3000 and hydraulic power unit. 
Volume-3, Issue-9, September-2020

IJRESM journals.resaim.com/ijresm | ISSN (Online): 2581-5792 | RESAIM Publishing

\begin{tabular}{|c|c|c|c|c|}
\hline S. No. & Properties & TI-6AL-4V & SS316 & TI-6AL4V-SS316 \\
\hline 1 & HARDNESS & $300 \mathrm{BHN}$ & $165 \mathrm{BHN}$ & $310 \mathrm{BHN}$ \\
\hline 2 & TENSILE STRENGTH(ULIMATE) & $950 \mathrm{MPA}$ & $795 \mathrm{MPA}$ & $941 \mathrm{MPA}$ \\
\hline 3 & TENSILE STRENGTH(YIELD) & $880 \mathrm{MPA}$ & $206 \mathrm{MPA}$ & $906 \mathrm{MPA}$ \\
\hline 4 & ELONGATION & $14 \%$ & $40 \%$ & $13 \%$ \\
\hline 5 & DENSITY & $4.512 \mathrm{G} / \mathrm{CM}^{\wedge} 3$ & $0.290 \mathrm{Ib} / \mathrm{in}^{\wedge} 3$ & $3.93 \mathrm{G} / \mathrm{CM} 3$ \\
\hline 6 & MELTING POINT & $1660 * \mathrm{C}$ & $1420 * \mathrm{c}$ & $1690^{*} \mathrm{C}$ \\
\hline 7 & REDUCTION AREA & $36 \%$ & $30 \%$ & $34 \%$ \\
\hline 8 & MODULUS OF ELASTICITY & $113.8 \mathrm{GPA}$ & $164 \mathrm{GPA}$ & $116 . \mathrm{GPA}$ \\
\hline
\end{tabular}

- The extensometers, the grips and the printer are options and should be ordered separately according to the needs of the user.

The machine is capable of performing the following tests:
a) Tension
b) Compression
c) Transverse
d) Bending
e) Shear
f) Hardness

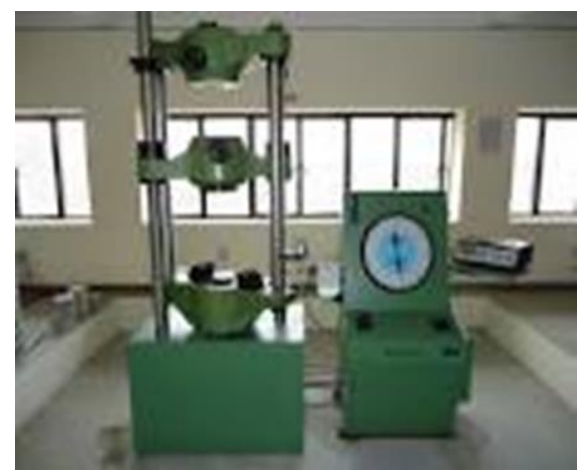

Fig. 4. Universal testing machine

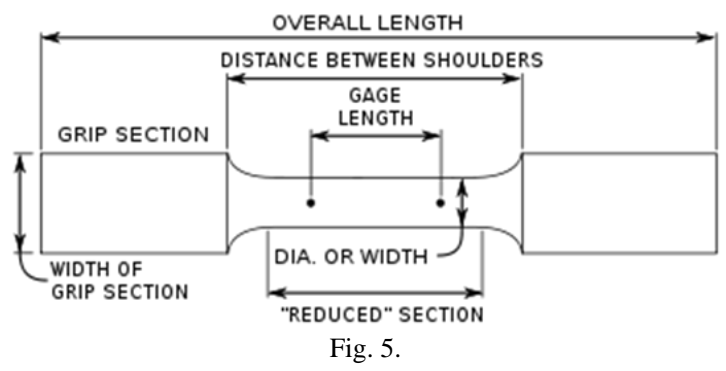

\section{Conclusion}

In this work, the newly designed and fabricated titanium alloy composite with different materials and compositions were tested. After performing various tests like Brinell hardness, tensile, flexural method to calculate the hardness, elongation, compression and wear. We can conclude that the titanium alloy and stainless steel composite with $10 \%$ SS shows the better performance compare the another one.

\section{References}

[1] R. Boyer, G. Welsch, E.W. Collings, Materials Properties Handbook----Titanium Alloys, ASM international, 1994.

[2] M. F. Ashby, D.R.H. Jones, Engineering Materials 1--An Introduction to their Properties and Applications, 2nd edition ed., Reed Elsevier plc group, Oxford, 1996

[3] G. Lutjering, J.C. Williams, Titanium, 2nd ed., Springer, Berlin Heidelberg, 2003.

[4] W.G. Burgers, Physica, 1 (1934) 561-586.

[5] C.J. McHargue, Acta Crystallographica, 6 (1953) 529-530.

[6] T. Karthikeyan, S. Saroja, M. Vijayalakshmi, Scripta Materialia, 55 (2006) 771-774.

[7] B. Srikumar, M. Pradip, Phase Transformations Examples from Titanium and Zirconium Alloys, Elsevier, Amsterdam, 2007.

[8] I. Polmear, Light Alloys, 4th edition ed., Butterworth-Heinemann, Oxford, 2006

[9] L. J. Hunter, School of Metallurgy and Materials Science, University of Birmingham, Birmingham, 1997, pp. 1-43.

[10] J. Esslinger, MTU aero Engines, Munich, Germany, Munich, 2003.

[11] W.B. Pearson, B. William, A handbook of lattice spacings and structures of metals and alloys / W.B. Pearson. Vol. 2., Pergamon, Oxford, 1967.

[12] H. Fujiwara, R. Yonezawa, K. Ameyama, J. Japan Inst. Metals, 62(1988), 9.

[13] Y. N. Wang, J. C. Huang, Materials Chemistry and Physics, 81 (2003) 1126.

[14] M. J. Donachie, JR, American society for metals, Metals Park, Ohio, 1982 , pp. 392.

[15] S. Nag, Materials Science and Engineering, The Ohio State University, Ohio, 2008, pp. 315.

[16] T. Ahmed, H.J. Rack, Materials Science and Engineering A, 243 (1998) 206-211.

[17] E. A. Brandes, Butterworth \& Co (Publishers) Ltd. London, 1983.

[18] R. Abbaschian, L. Abbaschian, R.E. Reed-Hill, Physical Metallurgy principles, Fourth Edition ed., Cengage learning, Stamford, 2010.

[19] E. K. Molchanova, Phase Diagrams of Titanium Alloys, The Israel Program for Scientific Translations, Jersualem, 1965.

[20] J. C. Williams, R. I. Jaffee, H. M. Burte (Eds.) Tianium Science and Technology, Plenum Press, New York, London, California, 1973. 